\title{
Synergistic Action of Triiodothyronine and Hydrocortisone on Epinephrine-Induced Reabsorption of Fetal Lung Liquid
}

\author{
P. M. BARKER, M. MARKIEWICZ, K. A. PARKER, D. V. WALTERS, AND L. B. STRANG \\ Department of Paediatrics, University College and Middlesex School of Medicine, Rayne Institute, London \\ WCIE 6JJ, United Kingdom
}

\begin{abstract}
The influence of triiodothyronine and hydrocortisone on maturation of the response to epinephrine that leads to reabsorption of lung liquid was investigated in nine chronically catheterized fetal sheep. Experiments were performed on thyroidectomized fetal sheep at 116-120 d gestation, well before the reabsorptive response to epinephrine is normally seen. After i.v. administration of either triiodothyronine $(60 \mu \mathrm{g} / \mathrm{d})$ or hydrocortisone $(10 \mathrm{mg} /$ d) for $3 \mathrm{~d}$ (three fetuses in each case), all fetuses continued to secrete lung liquid during exposure to epinephrine (secretion rate $=5.9 \pm 3.2 \mathrm{~mL} / \mathrm{h}$ in triiodothyronine-treated and $4.4 \pm 1.9 \mathrm{~mL} / \mathrm{h}$ in hydrocortisone-treated fetuses). However, when the two hormones were administered together in the same doses to three fetuses, a striking reabsorptive response to epinephrine was seen (absorption rate $=-12.3 \pm 3.6 \mathrm{~mL} / \mathrm{h}$ ), similar to that observed in the mature fetus. Induction of this capacity to reabsorb lung liquid may be of importance in the management of respiratory problems of the newborn infant. (Pediatr Res 27: 588-591, 1990)
\end{abstract}

Abbreviations

$T_{3}$, triiodothyronine

$\mathrm{T}_{4}$, thyroxine

TRH, thyrotropin-releasing hormone

The secretion of lung liquid by the pulmonary epithelium maintains expansion and promotes development of the fetal lung $(1,2)$. At birth, however, effective aeration of this organ is dependent on rapid reabsorption of the liquid from its alveolar spaces $(3,4)$. The switch from secretion to absorption depends on a reversal in direction of net ion transport across the pulmonary epithelium, brought about by a change from active chloride transfer into the alveolar lumen (2) to the active transport of sodium from the lumen towards the interstitium (5). This change is normally activated by a rise in fetal plasma epinephrine brought about by the stress of labor and delivery (4). In the fetal sheep (gestation $=147 \mathrm{~d}$ ), a reabsorptive response to infusion of i.v. epinephrine in the fetus is seen from about $130 \mathrm{~d}(3,4)$, and this response increases more than 20 -fold in the last 2 wk of gestation. We have undertaken an investigation of hormones that might control the maturation of this reabsorptive response. We have shown previously that thyroidectomy prevents development of the reabsorptive response (6) and that this can be restored by the infusion of $\mathrm{T}_{3}$ to the thyroidectomized fetus (7).

Received October 30, 1989; accepted January 24, 1990.

Correspondence: Dr. D. Walters, Department of Paediatrics, University College and Middlesex Medical School, University Street, London WC1 6JJ, UK.
However, precocious exposure of the fetus to $T_{3}$ at an early gestation did not significantly advance the time of appearance of this reabsorptive capacity, from which it could be concluded that some other factor must play a role in determining its maturation during gestation. Steroid hormones, alone or in combination with thyroid hormones, are known to be important in determining the maturation of structural aspects of the lung and its surfactant system in the fetus $(8,9)$. Our experiments were undertaken to examine the influence of hydrocortisone alone and in combination with $T_{3}$ on the maturation of the reabsorptive response. Fetal sheep were studied at 116-120 d, which is a gestation well before that at which the reabsorptive response to epinephrine normally appears.

\section{MATERIALS AND METHODS}

Experimental preparation. The surgical preparation of chronically-catheterized fetal sheep to allow for repeated measurement of lung liquid secretion or absorption rate was identical to that described in detail by Walters and Olver (3). Nine dated, pregnant ewes were operated on at 112-115 d gestation under general anesthesia induced by thiopentone and maintained with fluothane. Fetal thyroidectomy was carried out and wide bore (inner diameter, $2.6 \mathrm{~mm}$ ) catheters placed into each end of the incised fetal trachea, finer gauge catheters were inserted into the carotid artery and jugular vein. The catheters were brought out through the uterus and flank of the ewe and the tracheal catheters joined to form an external loop that allowed uninterrupted flow of lung liquid from the fetal lung to the larynx between experiments. After surgery, antibiotics were given for the first $48 \mathrm{~h}$ to the ewe (streptomycin $500 \mathrm{mg}$ intramuscularly, benzyl penicillin $300 \mathrm{mg}$ intramuscularly) and to the fetus (streptomycin $70 \mathrm{mg}$ i.v., benzyl penicillin $50 \mathrm{mg}$ i.v.). No experiments were performed during this recovery period.

Experimental procedure. The measurement of lung liquid secretion or absorption depends on the use of an impermeant tracer $\left({ }^{125} \mathrm{I}\right.$-albumin) added to lung liquid. Dilution of the tracer over a time period of $30 \mathrm{~min}$ by newly formed liquid allows accurate determination of secretion rate, whereas an increase in concentration reflects a diminution in volume, or reabsorption. Under sterile conditions, the exteriorized loop of tracheal catheter was interrupted and the distal (lung) half was connected to a glass burette into which approximately half of the lung liquid could be withdrawn by gravity. The impermeant tracer was added to this reservoir and thoroughly mixed into lung liquid by repeated raising and lowering of the burette. After half an hour of mixing, the resting secretion rate was calculated from the changing concentration of tracer in seven samples of lung liquid taken at 5-min intervals over $30 \mathrm{~min}$. In the second half of the experiment, similar measurements were made during epinephrine infusion $(0.5 \mu \mathrm{g} / \mathrm{min})$ over a 30 -min period commencing 15 min after the start of the infusion. In both control and thyroid- 
ectomized fetuses, infusion of epinephrine at this rate has been shown to increase resting fetal plasma epinephrine concentration from about $0.1 \mathrm{ng} / \mathrm{mL}$ to about $1.0 \mathrm{ng} / \mathrm{mL}(4,6)$. Samples of carotid arterial blood were taken from the fetal carotid artery catheter for blood gas determinations and fetal hormone analysis before and during epinephrine infusion. Blood samples were immediately separated and the plasma stored at $-40^{\circ} \mathrm{C}$ for later analysis. Arterial blood pressure and heart rate were measured by means of a transducer set at the estimated level of the fetal heart, which allowed for measurement of heart rate and relative changes in mean blood pressure during the experiment but precluded measurement of absolute blood pressure. At the end of the experiment, the epinephrine infusion was discontinued, sulphmethazine was mixed into the lung liquid and given i.v. ( $165 \mathrm{mg}$ into each compartment) to reduce the risk of infection, and the tracheal loop reestablished to allow normal flow of lung liquid to the fetal larynx.

Infusion of $T_{3}$, hydrocortisone, or $T_{3}$ and hydrocortisone. Before starting the hormone infusion, a control experiment was performed as described above to measure the secretion rates of lung liquid before and during epinephrine infusion. The infusion of $\mathrm{T}_{3}$ alone, hydrocortisone alone, or $\mathrm{T}_{3}$ and hydrocortisone together was then started and continued for $3 \mathrm{~d}$ (Grasby Syringe Driver, Grasby Medical Ltd., Watford, Herts, UK, Ms16). The daily dose of $\mathrm{T}_{3}(60 \mu \mathrm{g} / \mathrm{d}$, Glaxo Labs, Ltd., London, England), hydrocortisone succinate $(10 \mathrm{mg} / \mathrm{d}$, Upjohn, Crawley, England), or the two hormones in combination (same doses) were diluted in $10 \mathrm{~mL}$ sterile water and infused continuously over $24 \mathrm{~h}$. (See Discussion for explanation of high $\mathrm{T}_{3}$ dosage.) There were three fetuses in each treatment group. After $3 \mathrm{~d}$ of hormone administration, a second experiment was performed to determine any hormonal influence on resting and epinephrine-stimulated lung liquid flow.

Hormone concentrations. Fetal plasma $\mathrm{T}_{3}, \mathrm{~T}_{4}$, and cortisol concentrations were measured using commercially available radioimmunoassay kits (Amersham International, Little Chalfont, Buckinghamshire, UK).

All values given are mean $\pm \mathrm{SD}$. Where paired observations were made, a paired $t$ test is used.

\section{RESULTS}

$T_{3}$ and cortisol concentrations. At the time of the first experiment (2-4 d after surgery), fetal plasma $T_{4}$ and $T_{3}$ concentrations had fallen to very low levels (mean $\mathrm{T}_{4}, 14.8 \pm 5.1 \mathrm{ng} / \mathrm{mL}$; mean $\mathrm{T}_{3}, 0.12 \pm 0.06 \mathrm{ng} / \mathrm{mL}$ ) as a result of fetal thyroidectomy [normal values for fetuses of $120-130 \mathrm{~d}$ gestation: $\mathrm{T}_{4} 98.8 \mathrm{ng} / \mathrm{mL}, \mathrm{T}_{3}$ $0.21 \mathrm{ng} / \mathrm{mL}(6)]$. Following $3 \mathrm{~d} \mathrm{~T}_{3}$ infusion, mean $T_{3}$ concentration rose from $0.14 \pm 0.08 \mathrm{ng} / \mathrm{mL}$ to $0.96 \pm 0.63 \mathrm{ng} / \mathrm{mL}$, and, after $3 \mathrm{~d}$ combined $\mathrm{T}_{3}$ and hydrocortisone infusion, from $0.06 \pm$ $0.05 \mathrm{ng} / \mathrm{mL}$ to $0.5 \pm 0.26 \mathrm{ng} / \mathrm{mL}$. Three $\mathrm{d}$ after hydrocortisone infusion, plasma cortisol had risen from $1.05 \pm 0.35 \mu \mathrm{g} / \mathrm{dL}$ to $14.03 \pm 12.82 \mu \mathrm{g} / \mathrm{dL}$, and, after combined hormone infusion, from $1.03 \pm 0.87 \mu \mathrm{g} / \mathrm{dL}$ to $5.9 \pm 1.56 \mu \mathrm{g} / \mathrm{dL}$. These concentrations of both $\mathrm{T}_{3}$ and hydrocortisone were similar to those normally seen in the fetal sheep a few days before delivery $(10,11)$.

Fetal blood pressure, heart rate, and arterial blood gas monitoring. All three experimental groups of fetuses showed similar rises in mean blood pressure and heart rate during epinephrine infusion both before and after exposure to hormones. Thus, the increases during epinephrine infusion before hormone administration were: blood pressure, $4.2 \pm 2.9 \mathrm{~mm} \mathrm{Hg}$ and heart rate, $13.3 \pm 10.9$ beats/min, whereas, after $3 \mathrm{~d}$ of hormone exposure, these increases were $3.6 \pm 3.3 \mathrm{~mm} \mathrm{Hg}$ and $9.5 \pm 10.1$ beats/ min. Epinephrine infusion caused a small fall in $\mathrm{pH}(7.39 \pm 0.03$ to $7.37 \pm 0.03, p<0.05)$ and a small rise in $\mathrm{PCO}_{2}(45.7 \pm 4.8$ to $48.4 \pm 5.1, p<0.05)$. There were no differences in these measurements between the three groups and no changes in $\mathrm{PO}_{2}$ were detected.

The effect of $T_{3}$, hydrocortisone, and combined $T_{3}$ and hydro- cortisone on response of lung liquid secretion/absorption to epinephrine. In all three groups of fetuses, after $3 \mathrm{~d}$ of hormone exposure, there was a similar rise in resting (preepinephrine infusion) secretion rate $(6.2 \pm 1.4 \mathrm{~mL} / \mathrm{h}$ to $9.1 \pm 3.7 \mathrm{~mL} / \mathrm{h}, n=$ $9, p<0.05$ ). In all three groups, the control epinephrine infusion before $\mathrm{T}_{3}$, hydrocortisone, or combined hormone exposure produced the small, expected decrease in secretion rate normally seen at this gestation (Table 1 ). In both the $T_{3}$ and hydrocortisone-infused groups, the secretion rates during epinephrine infusion in the 2 nd experiments after $3 \mathrm{~d}$ hormone exposure were no different from those in the 1 st prehormone experiment. However, in the three fetuses treated with a combination of $\mathrm{T}_{3}$ and hydrocortisone, there was a most striking reabsorptive response to epinephrine at $120 \mathrm{~d}$ gestation, comparable to that normally seen in the euthyroid fetus at 135 to $140 \mathrm{~d}$ (Figure 1).

\section{DISCUSSION}

These results show that the combined action of $\mathrm{T}_{3}$ and hydrocortisone can induce changes in the ion transport mechanism of the pulmonary epithelium in the fetal sheep, enabling it to respond to $\beta$-adrenergic stimulation at a much earlier age than is normally observed. Both these hormones are clearly necessary

Table 1 . Secretion $(+)$ or absorption $(-)$ rates $(m L / h)$ of fetal lung liquid before $\left(J_{V_{C}}\right)$ and during $\left(J_{V_{E}}\right)$ epinephrine infusion

$(0.5 \mu \mathrm{g} / \mathrm{min})$ in nine thyroidectomized fetal sheep in single experiments performed before and $3 d$ after being administered $T_{3}$, hydrocortisone $(\mathrm{Hc})$, or $T_{3}$ and hydrocortisone

\begin{tabular}{|c|c|c|c|c|}
\hline & \multicolumn{2}{|c|}{$\begin{array}{c}\text { Before } \\
\text { hormone }\end{array}$} & \multicolumn{2}{|c|}{ After hormone } \\
\hline & $\mathrm{J}_{\mathrm{V}_{\mathrm{C}}}$ & $\mathbf{J}_{\mathrm{V}_{\mathrm{E}}}$ & $\mathrm{J}_{\mathrm{V}_{\mathrm{C}}}$ & $\mathrm{J}_{\mathrm{V}_{\mathrm{E}}}$ \\
\hline \multirow[t]{3}{*}{$T_{3}$-infused group } & +5.8 & +2.8 & +7.1 & +2.4 \\
\hline & +8.6 & +5.7 & +14.4 & +8.6 \\
\hline & +7.1 & +3.5 & +6.2 & +6.8 \\
\hline \multirow[t]{3}{*}{ Hc-infused group } & +5.8 & +7.4 & +14.3 & +6.6 \\
\hline & +7.2 & +5.9 & +9.5 & +3.8 \\
\hline & +5.1 & +1.2 & +5.5 & +2.9 \\
\hline \multirow[t]{3}{*}{$\mathrm{T}_{3}$ and $\mathrm{Hc}$-infused group } & +7.1 & +2.5 & +11.1 & -15.8 \\
\hline & +2.8 & +1.8 & +4.3 & -12.4 \\
\hline & +4.0 & +4.0 & +4.3 & -8.6 \\
\hline
\end{tabular}

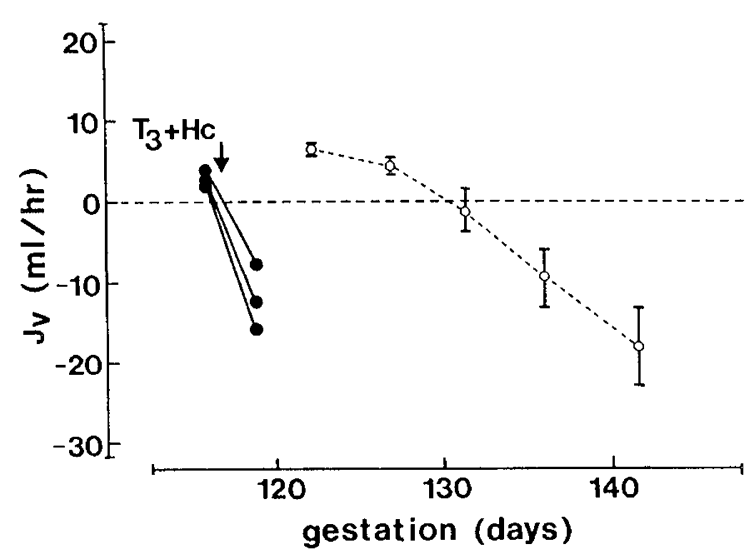

Fig. 1. Values of lung liquid secretion rate $\left(\mathrm{J}_{\mathrm{v}}\right)$ or reabsorption rate $\left(-J_{v}\right)$ during i.v. epinephrine infusion $(0.5 \mu \mathrm{g} / \mathrm{min})$ plotted against gestational age (d). The resting secretion rates before epinephrine infusion are not shown. $\bullet$, values from three thyroidectomized fetal sheep before $(116 \mathrm{~d})$ and $3 \mathrm{~d}$ after $(119 \mathrm{~d})$ continuous infusion of $T_{3}(60 \mu \mathrm{g} / \mathrm{d})$ and hydrocortisone $(10 \mathrm{mg} / \mathrm{d})$. $O$, mean $( \pm \mathrm{SEM}) J_{\mathrm{v}}$ for 25 nonthyroidectomized fetuses grouped in 5-d gestations from 120 to $145 \mathrm{~d}$ [from Brown et al. (4)]. 
for this development as neither hormone alone produced any change in the response to epinephrine.

Hormone concentrations and timing of reabsorptive response. The gestation at which the lung liquid reabsorptive response to epinephrine first appears in the fetal sheep coincides with increases in the concentrations of both thyroid and steroid hormones in fetal plasma. Maturation of the $\beta$-ring deiodination pathway required for conversion of $T_{4}$ to its active metabolite $T_{3}$ does not take place to any significant extent in the fetal sheep until after $130 \mathrm{~d}$ gestation (10) so that fetal plasma concentrations of $T_{3}$ remain low $(0.2 \mathrm{ng} / \mathrm{mL}$ or less $)$ in the sheep until the last $3 \mathrm{wk}$ of gestation during which time a gradual rise in $\mathrm{T}_{3}$ concentrations to about $0.5 \mathrm{ng} / \mathrm{mL}$ is seen (11). Very high doses of $\mathrm{T}_{3}$ were needed to produce the required plasma concentrations because $T_{3}$ is cleared much more rapidly in the fetus (12) than in the postnatal animal; this is probably the result of very active conversion of $T_{3}$ to $T_{2}$ (diiodothyronine) by $\alpha$-monoiodination in the placenta (13). Fetal plasma cortisol concentrations are similarly low throughout most of gestation, principally as a result of conversion by the placenta of fetal and maternal cortisol to its inactive metabolite cortisone (14). A gradual rise in fetal cortisol concentration is seen in the fetal sheep from about $130 \mathrm{~d}$ (15). Nathanielsz et al. (16) reported a later, more pronounced rise in cortisol concentrations to $10 \mu \mathrm{g} / \mathrm{dL}$ only in the last few days before delivery. Thus, hormone concentrations encountered by fetuses at gestations less than $120 \mathrm{~d}$ in our experiments were similar to those normally seen only close to full term.

Probable site of action of $T_{3}$ and hydrocortisone. The reabsorption of lung liquid induced by epinephrine is mediated by the net flux of sodium ions across the pulmonary epithelium from the alveolar lumen (5). Since this sodium-led reabsorption can be blocked by micromolar concentrations of amiloride in lung liquid (5), it has been inferred that the "opening" or activation of sodium channels in the apical membranes of epithelial cells constitutes the crucial change underlying epinephrine-induced absorption. A similar pattern of maturation is seen when dibutyryl cAMP is used to initiate the reabsorptive response (17), and this development can be completely inhibited in the sheep by fetal thyroidectomy at $118 \mathrm{~d}$ (6). It follows, therefore, that the maturation of this reabsorptive response depends not on adrenoreceptor development but on changes in some components beyond cAMP in the intracellular signalling system. The synergistic action of $\mathrm{T}_{3}$ and hydrocortisone can probably be attributed to stimulation of synthesis of proteins that control, or are part of, the structure of the apical membrane sodium channels. The increase in the resting secretion rate during $\mathrm{T}_{3}$ and hydrocortisone infusion is likely to reflect the normal rise in secretion rate seen during this part of gestation (4) rather than $\mathrm{a}_{3}$ /hydrocortisone-related effect, particularly as the secretion rate increased similarly in all three groups.

Clinical implications. Of all the pulmonary adaptations taking place at birth, the most obvious, the least studied, and possibly the most important is the change from the liquid-filled to the air-filled state. Similarly, it seems probable that the importance of inadequate reabsorption or continuing secretion of pulmonary liquid in preterm infants has not been adequately recognized as a cause of neonatal respiratory difficulties. It has been known for some time that $T_{3}$ and corticosteroids appear to act in concert to advance structural maturation (9) and to promote surfactant synthesis in both organ cultures of the fetal rat lung and the intact fetal rat (18). More recently, Warburton et al. (19) found that administration of corticosteroids and TRH together to the fetal sheep led to maturation of the surfactant system and improved lung mechanics. Both of these effects were enhanced when a $\beta$-agonist was infused in addition to the hormones. Similarly, Schellenberg et al. (20) have shown that a combination of $\mathrm{T}_{3}$, hydrocortisone, and prolactin infused into the fetal sheep increased lung distensibility and stability. Interestingly, Liggins et al. (21) found that although a significant increase in alveolar lavage-saturated phosphotidylcholine occurred in response to
TRH infused to sheep fetuses from 124 to 128 d gestation, improvement in lung distensibility and stability was not seen unless TRH was infused together with cortisol. In light of our findings, these results may have been partly or mainly due to the effect of these hormones on the pulmonary liquid reabsorptive system.

In the context of our experiments, very premature infants are most likely to be born at a stage when the lungs have had insufficient prenatal exposure to $\mathrm{T}_{3}$ and corticosteroid hormones. Mean cord concentrations of both these hormones are known to be significantly lower in infants born preterm $(22,23)$, and it has been shown that, within the preterm group, low cord concentrations of both thyroid hormones (24) and cortisol (23) at birth are associated with a higher incidence of subsequent respiratory problems. Lucas et al. (25) report that $50 \%$ of $\mathrm{T}_{3}$ concentrations in the first $36 \mathrm{~h}$ of life were below $0.19 \mathrm{ng} / \mathrm{mL}(0.3 \mathrm{nM})$, whereas the results obtained by Barker et al. (26) suggested that concentrations over $0.3 \mathrm{ng} / \mathrm{mL}$ may be required to induce the reabsorptive mechanism in the fetal sheep. Although it appears that many preterm infants are able to mount a substantial postnatal surge in $T_{3}(22)$, this would be too late to prevent the onset of respiratory difficulties that may be associated with poor lung liquid clearance in the first $24 \mathrm{~h}$ of life.

Our experiments show that the reabsorptive response to epinephrine can be induced much earlier in gestation than is normally seen, and within a short time scale (Fig. 1), by exogenous administration of $\mathrm{T}_{3}$ and hydrocortisone. The relative independence of this aspect of lung development from any fixed developmental program and its ability to respond to hormones at a very early stage of gestation may be important factors in determining the severity of respiratory disease in those very small preterm infants who have had insufficient prenatal exposure to $\mathrm{T}_{3}$ and hydrocortisone. Since cortisol and $\mathrm{T}_{3}$ concentrations can be manipulated both pre- $(27,28)$ and postnatally, it may be possible to use these hormones to enhance the lung liquid reabsorptive capacity of the immature lung.

\section{REFERENCES}

1. Alcorn $\mathrm{D}$, Adamson TM, Lambert TF, Maloney JE, Ritchie BC, Robinson PM 1977 Morphological effects of chronic tracheal ligation and drainage in the fetal lamb lung. J Anat 123:649-660

2. Olver RE, Strang LB 1974 Ion fluxes across the pulmonary epithelium and the secretion of lung liquid in the foetal lamb. J Physiol 241:327-357

3. Walters DV, Olver RE 1978 The role of catecholamines in lung liquid absorption at birth. Pediatr Res 12:239-242

4. Brown MJ, Olver RE, Ramsden CA, Strang LB, Walters DV 1983 Effects of epinephrine and of spontaneous labour on the secretion and absorption of lung liquid in the fetal lamb. J Physiol 344:137-152

5. Olver RE, Ramsden CA, Strang LB, Walters DV 1986 The role of amilorideblockable sodium transport in epinephrine-induced lung liquid reabsorption in the fetal lamb. J Physiol 376:321-340

6. Barker PM, Brown MJ, Ramsden CA, Strang LB, Walters DV 1988 The effect of thyroidectomy in fetal sheep on lung liquid reabsorption induced by epinephrine or cyclic AMP. J Physiol 407:373-383

7. Barker PM, Strang LB, Walters DV 1989 The role of triiodothyronine $\left(\mathrm{T}_{3}\right)$ in the maturation of epinephrine-induced reabsorption of lung liquid in the fetal sheep. J Physiol 416:51(abstr)

8. Liggins GC 1976 Adrenocortical-related maturational events in the fetus. Am J Obstet Gynecol 126:931-939

9. Gross I, Dynia DW, Wilson CM, Ingleson LD, Gewolb IH, Rooney SA 1984 Glucocorticoid-thyroid hormone interactions in the fetal rat lung. Pediatr Res 18:191-195

10. Wu SY, Klein AH, Chopra IJ, Fisher DA 1978 Alterations in tissue thryoxine 5 -monodeiodinating activity in the perinatal period. Endocrinology 103:235-239

11. Fisher DA, Dussault JH, Sack J, Chopra IJ 1977 Ontogenesis of hypothalamicpituitary thyroid function and metabolism in man, sheep and rat. Recent Prog Horm Res 33:59-107

12. Fraser M, Liggins GC 1988 Thyroid hormone kinetics during late pregnancy in the ovine fetus. J Dev Physiol 10:461-471

13. Roti E, Braverman LE, Fang S, Alex S, Emerson CH 1982 Ontogenesis of placental inner ring thyroxine deiodinase and amniotic fluid $3,3^{\prime}, 5^{\prime}$-triiodothyronine concentration in the rat. Endocrinology 111:959-963

14. Buster JE 1983 Gestational changes in steroid hormone biosynthesis, secretion, metabolism and action. Clin Perinatal 10:527-552

15. Ballard PL, Kitterman JA, Bland RD, Clyman RI, Gluckman PD, Platzker CG, Kaplan SL, Grumbach MM 1982 Ontogeny and regulation of cortico- 
steroid binding globulin capacity in the plasma of fetal and newborn lambs. Endocrinology 1 10:359-366

16. Nathanielsz PW, Comline RS, Silver M, Paisey RB 1972 Cortisol metabolism in the fetal and neonatal sheep. J Reprod Fertil [Suppl] 16:39-59

17. Olver RE, Ramsden CA, Walters DV 1987 The effect of dibutyryl cyclic AMP on lung liquid volume flow across the pulmonary epithelium of the fetal sheep. J Physiol 391:61(abstr)

18. Hitchcock KB 1979 Hormones and the lung. 1. Thyroid hormones and glucocorticoids in lung development. Anat Rec 194:15-40

19. Warburton D, Parton L, Buckley S, Cosico L, Enns G, Saluna T 1988 Combined effects of corticosteroid, thyroid hormones, and $\beta$-agonist on surfactant, pulmonary mechanics, and $\beta$-receptor binding in fetal lamb lung. Pediatr Res 24:166-170

20. Schellenberg JC, Liggins GC, Manzai M, Kitterman JA, Lee CH 1988 Synergistic hormonal effects on lung maturation in fetal sheep. $\mathbf{J}$ Appl Physio 65:94- 100

21. Liggins GC, Schellenberg JC, Manzai M, Kitterman JA, Lee CH 1988 Synergism of cortisol and thyrotropin-releasing hormone in lung maturation in fetal sheep. J Appl Physiol 64:1880-1884
22. Cuestas RA 1978 Thyroid function in healthy premature infants. Pediatrics 92:963-967

23. Sybulski S, Maughan GB 1976 Relationship between cortisol levels in umbilical cord plasma and the development of the respiratory distress syndrome in premature newborn infants. Am J Obstet Gynecol 125:239-243

24. Cuestas RA, Lindall A, Engel RE 1976 Low thyroid hormones and respiratory distress syndrome of the newborn. Studies on cord blood. N Eng J Med 295:297-302

25. Lucas A, Rennie J, Baker BA, Morley R 1988 Low plasma triiodothyronine concentrations and outcome in preterm infants. Arch Dis Child 63:12011206

26. Barker PM, Walters DV, Strang LB 1990 The role of thyroid hormones in maturation of the adrenaline-sensitive lung-liquid reabsorptive mechanism in fetal sheep. J Physiol 424:473-485

27. Roti E Gnudi A, Braverman LE, Robuschi G, Emanuele R, Bandini P, Benass L, Pagliani A, Emerson CH 1981 Human cord blood concentrations of thyrotropin, thyroglobulin, and iodothyronines after maternal administration of thyrotropin-releasing hormone. J Clin Endocrin Metab 53:813-819

28. Ballard PL, Liggins GC 1982 Glucocorticoid activity in cord serum: comparison of hydrocortisone and betamethasone regimes. Pediatr Res 101:468-471 